\title{
ADORNO E BECKETT: APORIAS DA AUTONOMIA DO DRAMA
}

\author{
Luciano Gatti* \\ lfgatti@gmail.com
}

RESUMO $O$ artigo procura situar a interpretação proposta por Theodor W. Adorno para a peça "Fim de partida", de Samuel Beckett, no contexto de sua concepção de autonomia da arte. Segundo a hipótese do trabalho, o conceito de autonomia subjaz ao diagnóstico histórico de Adorno a respeito do gênero dramático, o qual justifica sua leitura da peça como uma paródia do drama. O artigo busca mostrar os acertos dessa leitura perante a recepção inicial da peça, e também seus limites, uma vez que resulta em uma abordagem da experiência teatral focada primordialmente na consideração do texto teatral, em detrimento da encenação.

Palavras-chave Theodor W. Adorno, Samuel Beckett, drama, autonomia da arte.

ABSTRACT This article aims to situate the interpretation proposed by Theodor W. Adorno for Samuel Beckett's play "Endgame" in the context of his conception of the autonomy of art. According to the hypothesis of this essay, the concept of autonomy underlies Adorno's historic diagnostic about the dramatic genre, which justifies his analysis of the play as a parody of drama. The article seeks to demonstrate the successes of this reading in face of the play's early reception, as well as its limitations, since it results in an approach 
to the theatrical experience primarily focused on regarding the theatrical text, at the expense of the staging.

Keywords Theodor W. Adorno, Samuel Beckett, drama, autonomy of art.

Quando Theodor W. Adorno escreveu seu ensaio sobre "Fim de partida", sua intenção era polêmica. Na virada dos anos 1960, o teatro de Samuel Beckett era apropriado pela moda existencialista francesa e se transformava rapidamente em ilustração da ausência de sentido da condição humana na era da Guerra Fria. Destruição, guerra e absurdo metafísico eram as palavraschave desta primeira recepção, cristalizada e difundida no influente livro de Martin Esslin, "Teatro do absurdo" (1961), onde Beckett compõe o panorama do novo teatro europeu ao lado de dramaturgos - Ionesco, Adamov, Genet - com quem ele não tinha muito a ver. Não foram poucos os que tentaram encontrar um sentido universal por trás da rotina aparentemente sem propósito dos quatro personagens confinados a um lugar descrito apenas como "refúgio" ou "abrigo". Nas primeiras resenhas, referências ao desespero e à falta de esperança em um mundo pós-apocalíptico eram um lugar-comum no intuito de caracterizar a sobrevida de Hamm, Clov, Nagg e Nell como uma situação terminal. ${ }^{1}$

Ao mobilizar "Fim de partida" contra esta primeira recepção, a necessidade mesma de explicar e encontrar sentido, juntamente com outros pressupostos da metafísica existencialista, é colocada em questão. Como a prosa de Kafka, também um objeto da atenção de Adorno, "Fim de partida" evidenciaria o caráter obsoleto de qualquer interpretação definida como recondução da configuração artística a uma ideia de sentido. Não haveria muito a encontrar por trás da peça, nenhuma visão de mundo transmitida por seu autor, nenhuma mensagem a ser decifrada por seu público. Hermética tanto diante do sentido metafisicamente assegurado quanto da representação de uma história efetiva para além da circunscrição do palco, "Fim de partida" exigiria outros critérios de interpretação. No contexto da recepção da peça, o mérito do ensaio de Adorno se mostra no fato de ele ter deixado em segundo plano as referências históricas ou filosóficas exteriores à peça, para insistir na historicidade do material empregado em sua produção. Atento à articulação interna do drama, 
sua interpretação se aproximou do exame mais concreto e filológico da materialidade da obra. Esta deveria responder pelas questões últimas, não o contrário. Mimetizando seu objeto, Adorno encontrava os critérios da crítica na obra mesma, a qual eliminara as referências externas mais óbvias para se concentrar no conflito entre os personagens.

Diante dos debates atuais sobre teatro, o ensaio de Adorno adquire novamente uma posição polêmica. Como será discutido ao longo desse trabalho, Adorno compreende a experiência teatral prioritariamente a partir do drama, ou seja, do texto teatral, conferindo à encenação um papel secundário, uma espécie de reservatório dos elementos ilusionistas do teatro. Uma das tendências fortes da teoria teatral contemporânea, em parte aglutinada em torno do debate provocado pelo livro de Hans Thies Lehmann, "Teatro pósdramático", é, por sua vez, a ênfase em uma experiência teatral na qual o drama não tem primazia alguma perante outros elementos que entram em conjunção na realização de um espetáculo. O drama estaria aqui abalado como representação de um conflito cujo traço estilístico central seria a contraposição de personagens por meio do diálogo. Além disso, na economia do espetáculo, o texto propriamente dito não seria mais o eixo centralizador, mas tão somente um elemento dentre outros - a cenografia, a iluminação, a música ou a presença física do ator - na composição do que se chama de "materialidade da cena". Sob muitos as aspectos, a ênfase na situação teatral ou em um teatro do real, como o defende Lehmann, se traduz no tratamento insuficiente, senão ingênuo, de conceitos-chave da estética teatral como mimèsis, representação e autonomia. Nesse contexto, o caráter extemporâneo do ensaio adorniano poderia ter algo a dizer aos atuais debates a respeito da alegada superação do teatro dramático. Chamar a atenção para os motivos que o levaram a conferir tal primado ao texto dramático em detrimento de sua encenação, como será feito a seguir, permitirá discutir as aporias de uma compreensão da experiência teatral calcada em uma rigorosa concepção de autonomia da arte.

Na estética de Adorno, a primazia do drama perante sua encenação, assim como da partitura musical em relação à execução, só se justifica no contexto de uma compreensão mais ampla do conceito de obra de arte. A desconsideração deste dado poderia sugerir a antipatia deste autor pelo componente, por assim dizer, mais vivo da experiência estética. Pelo menos desde a década de 1930, a relação com o receptor é um elemento lateral de seu exercício crítico, tal como ele escreve a Horkheimer em 1938: "minha tese era a de que a teoria social 
da arte não deve trabalhar com as origens e com a psicologia do artista e nem primariamente com o efeito e com a recepção das obras de arte, mas com sua técnica própria enquanto instância representativa da sua produção" (Adorno; Horkheimer, 2004, p. 30). Embora o estudo da recepção das obras de arte não seja o ponto forte de sua reflexão, Adorno dedicou alguma atenção não só à questão da escuta musical, mas também a avaliar tendências de interpretação. Suas críticas à execução de peças de Bach com instrumentos de época como uma forma de historicismo musical o comprovam. ${ }^{2} \mathrm{~A}$ ideia mesma de experiência estética, no sentido da relação da obra de arte com seu receptor, não merece, contudo, um tratamento mais aprofundado. Diante disto, não são só os esforços de formular uma concepção de experiência estética a partir da Teoria estética que sofrem da falta de material de trabalho. ${ }^{3}$ As críticas à estética adorniana pela desconsideração do receptor, que o desqualificariam como referência de avaliação de fenômenos artísticos como a performance, o happening e a instalação, correm, por sua vez, o risco de perder de vista o mais interessante de seu trabalho: a consideração do objeto artístico propriamente dito, não do ponto de vista do processo produtivo, mas da coisa mesma produzida (cf. Rebentisch, 2003, pp. 101-145).

É assim que o primado dado por Adorno ao drama deve ser situado no interior do processo que confere à obra de arte o estatuto de coisa produzida: $\mathrm{o}$ movimento de autonomização da obra de arte em relação ao mundo empírico, cuja complexidade caberia ao conceito de aparência (Schein) circunscrever. $\mathrm{O}$ conceito de autonomia não se refere aqui somente ao esforço da obra de arte em negar finalidades externas a ela, como as do mercado, em vista do desenvolvimento de sua lógica imanente, fenômeno este analisado por Adorno em reflexões que vão da música nova à indústria cultural. A autonomia circunscreve também a objetivação da obra de arte como artefato. "Na medida em que as obras de arte são obras, elas são coisas em si mesmas, objetivadas em virtude de sua própria lei formal" (Adorno, 1997, pp. 152153). A defesa da autonomia depende do conceito de obra de arte: por um processo imanente de formalização, ela adquire este caráter paradoxal de coisa que a liberta do domínio do produtor e a disponibiliza à apropriação alheia, seja pelo mercado, seja pelo receptor ou ainda pelo intérprete ou encenador, como nos casos da partitura e do drama. A obra de arte é aqui um objeto

2 Cf. o ensaio "Em defesa de Bach contra seus admiradores", Adorno, 1998. Adorno deixou inacabada uma teoria da reprodução musical, cujos esboços foram publicados postumamente: Adorno, 2005. Para um comentário da questão, cf. Silva, 2006.

3 Cf. trabalhos de Menke, 1991; e Wellmer, 2002. 
como qualquer outro, socialmente produzido e alienado de seu produtor. Não é de estranhar que a noção mesma de fetichismo não seja exclusividade de suas análises dos produtos da indústria cultural, mas também perpasse sua reflexão sobre o processo de racionalização da obra de arte, ou seja, a conquista de autoconsciência pelo material artístico à medida que se liberta da obrigatoriedade de seu uso tradicional. Não é o caso de desenvolver esta questão aqui, mas apenas de salientar a dialética inscrita na autonomia da obra de arte: sua diferença em relação ao mundo empírico é indissociável de um processo social que confere a ela o caráter de coisa produzida. Não reconhecer a superioridade do texto perante sua execução equivaleria a desconhecer a dialética atuante na produção do drama e da partitura.

Que no drama a encenação seja considerada a coisa mesma e não o texto impresso, que na música seja o som vivo e não as notas na partitura, atesta a precariedade do caráter de coisa na arte, sem que, por isto, a obra seja liberta de sua participação no mundo das coisas. Partituras não são só quase sempre melhores que as execuções, mas também são mais que apenas indicações para as execuções; este mais é a coisa mesma. De resto, os dois conceitos de coisa da obra de arte não são incondicionalmente separáveis. (Adorno, GS 7, p. 153)

A objetivação da obra implica tanto esta participação no mundo das coisas quanto a reação a ela, uma tendência imanente graças à qual a obra busca distinguir-se do mundo empírico e afirmar sua autonomia. "A diferença das obras de arte em relação à empiria, seu caráter de aparência, se constitui nesta empiria e na tendência contra ela" (Adorno, GS 7, p. 158). Nomear esta diferença de aparência explicita a dialética entre a obra de arte e o mundo empírico: no caso de obras literárias, a diferença entre a obra e a realidade é imprescindível à simulação de realidade. Em outras palavras, a diferença é imprescindível à apresentação verossímil de uma possível realidade da qual vive o ilusionismo artístico. Uma das apresentações mais acessíveis a esta questão foi dada por Adorno ao comparar a reação do que ele entende por romance contemporâneo - o romance europeu das primeiras décadas do século XX - ao romance tradicional, ou seja, ao romance realista do século XIX cujo apogeu estaria no romance puro de Flaubert.

O romance tradicional [...] deve ser comparado ao palco italiano do teatro burguês. Essa técnica era uma técnica de ilusão. O narrador ergue uma cortina e o leitor deve participar do que acontece, como se estivesse presente em carne e osso. A subjetividade do narrador se afirma na força que produz essa ilusão e [...] na pureza da linguagem que, através da espiritualização, é ao mesmo tempo subtraída do âmbito da empiria, com o qual ela está comprometida. (Adorno, GS 11, p. 60) 
Como indica a referência ao palco italiano, o romance tradicional seria caracterizado por uma relação não problemática com o caráter de aparência ou de ilusão - aqui os termos são sinônimos - da obra de arte. Assim como na construção da cena autêntica valorizada por teóricos do teatro ilusionista como Diderot, também no romance tradicional o desafio reside em apagar os rastros do processo de formalização da obra. $\mathrm{O}$ material heterogêneo, assim como a reflexão de natureza intelectual, capaz de desviar a atenção do material narrativo para o trabalho de composição, é extirpado. Como a tela da pintura realista, a escrita romanesca também deve ser transparente.

O romance contemporâneo, por sua vez, se caracteriza pelo esforço de voltar-se contra o encobrimento de seu caráter de aparência, explicitado agora pelo próprio narrador como a "mentira da exposição". A reflexão é reintroduzida neste novo romance, mas não de maneira externa, alheia à constituição formal da obra. Ao contrário, agora sua função é imanente à forma, reformulando o papel convencional do narrador frente à sua narrativa. Ele sai dos bastidores, abandona os disfarces da onisciência e da onipresença e se apresenta ao leitor na figura daquele que busca, "como um atento comentador dos acontecimentos, corrigir sua inevitável perspectiva. A violação da forma é inerente a seu próprio sentido" (idem). Tal como o realce da textura da tela ou a queda da quarta parede, a explicitação do narrador não é mais um defeito de formalização, mas uma tendência inscrita no processo mesmo de conscientização do material artístico. A indistinção entre comentário e ação é lembrada como uma violação da forma imanente à forma do romance proustiano, por exemplo, o qual tateia incessantemente seu negativo ao fazer da composição do romance um de seus fios condutores. A forma refletida como conteúdo é o protesto contra o caráter de aparência da obra de arte.

Certamente este protesto implica novos problemas de composição. À medida que a explicitação da aparência revela a artificialidade do gesto instaurador da obra de arte - a tomada da palavra pelo narrador -, início e fim não demarcam mais os limites da diferença entre o mundo empírico e a obra fechada sobre si mesma, mas se revelam como instantes tênues e arbitrários de passagem entre esses dois âmbitos. Novamente Proust evidencia o problema ao confundir, no início de seu romance, as figuras do herói e do narrador. "O início da Recherche proustiana deve ser interpretado como a tentativa de driblar o caráter de aparência: conduzir sorrateiramente ao interior da mônada da obra de arte sem a instauração violenta da imanência de sua forma e sem a simulação de um narrador onipresente e onisciente" (Adorno, GS 7, p. 156).

Ao violar a totalidade da forma, como Proust revelando ao leitor a junção entre o início e o fim de seu romance, o realce da "mentira da exposição" 
também prejudica o uso das convenções formais na composição da obra de arte. Não só sua instauração se torna uma demarcação artificial, mas também o final é privado daquela necessidade capaz de arrematar a obra como totalidade fechada sobre si mesma. Adorno está aqui apontando para um problema central da peça de Samuel Beckett, "Fim de partida": a questão do fim, de como encaminhar o encerramento do jogo, trabalhado explicitamente como tema ao longo de toda peça.

Uma vez separada da convenção, é certo que nenhuma obra de arte foi mais capaz de terminar convincentemente; os finais tradicionais, por sua vez, só são convincentes por também simular como totalidade da forma a convergência temporal entre os momentos individuais e o ponto final. Em muitas obras modernas que alcançaram grande audiência, a forma foi mantida artificialmente aberta porque elas queriam dar forma ao fato de que a unidade da forma estava vedada a elas. A má infinitude, o não poder terminar, torna-se expressão e princípio de método livremente escolhido. A peça de Beckett, que, ao invés de concluir, se repete palavra por palavra, reage a isto. (Adorno, GS 7, p. 221)

Segundo estas colocações, Beckett teria lidado com o problema do fim convincente ao incorporá-lo como um tema. Ao invés de preparar sua resolução, o conflito entre Hamm e Clov se transforma num artifício para ensaiar e desacreditar tentativas de desenlace. É assim que sua irresolução pode ser vista como um sinal da conquista imanente pelo drama da consciência de seu caráter ilusório. Como se vê, Adorno não recorre a uma explicação metafísica da condição humana, muito menos a acontecimentos históricos cifrados, mas procura investigar a construção dramática da peça a partir da situação histórica do material artístico. Questões de conteúdos não se dissociam dos problemas formais, mas se iluminam reciprocamente. Diante deste estado da questão, não há possibilidade de progresso ou desenvolvimento tal como no drama do século XIX - a curva da ação dramática em vista da peripécia e da resolução - mas o contraponto não resolvível de temas que impulsionam e suspendem o progresso da ação. Nas falas de Hamm, por exemplo, o desejo de que as coisas cheguem ao seu fim é contraposto ao cuidado extremo com os detalhes ínfimos de sua própria sobrevivência. Falas como "está quase acabado" ou "algo segue seu curso", que se repetem ao longo do texto como temas musicais, explicitam a tendência da forma à resolução ao mesmo tempo que apontam, na ausência de desenvolvimento, para a impossibilidade de o conflito resolver-se, impedindo que o drama se feche como unidade de uma multiplicidade.

Tal diagnóstico permite então a Adorno caracterizar esta estranha configuração do drama. Se as convenções tradicionais diziam que o conflito 
entre os personagens, exposto formalmente no diálogo, encaminharia a ação, primeiro, para a intensificação do conflito e, depois, para sua resolução, conferindo unidade ao conjunto, "Fim de partida" faz uso destes termos sem sua função originária. $\mathrm{O}$ conceito de drama ganha então um novo sentido.

Qual é a razão de ser das formas quando desaparece sua tensão com aquilo que não lhes é homogêneo sem que por isso o progresso do domínio estético do material possa ser freado? Fim de partida escapa dessa dificuldade ao transformá-la em coisa sua, tornando-a seu tema. [...] Os constituintes do drama aparecem após sua morte. Exposição, complicação (Knoten), ação, peripécia e catástrofe retornam como elementos decompostos de uma autópsia da forma dramática. [...] Aqueles elementos constituintes naufragam juntamente com o sentido que outrora fazia parte do drama; Fim de partida estuda, como num tubo de ensaio, o drama da época atual, a qual não tolera mais o que constitui o drama. (Adorno, GS 11, p. 303)

Este emprego das formas artísticas no momento em que elas se encontram desprovidas de sua função originária foi expressamente conceituado por Adorno como paródia. O conceito aponta para as ruínas do drama apropriadas por "Fim de partida", mas não é só o distanciamento histórico em relação ao material artístico herdado da tradição que está em causa. "Fim de partida" não corresponderia a uma apropriação arbitrária de materiais desprovidos de seu caráter vinculante, de sua Verbindlichkeit, um fenômeno detectado por Adorno já na década de 1920 em seus primeiros escritos sobre o expressionismo. ${ }^{4}$ A peça não teria surgido de um cardápio de formas e convenções passadas disponibilizadas livremente ao gosto de seu autor. Ao contrário, sua formalização seria indissociável da conscientização imanente à configuração artística do caráter obsoleto de seu próprio material.

Elas [as categorias dramáticas] são todas parodiadas. Mas não se zomba delas. De maneira enfática, a paródia se define pela utilização de formas na época de sua impossibilidade. Ela demonstra essa impossibilidade e transforma deste modo as formas. As três unidades aristotélicas são conservadas, mas o drama mesmo perece. Assim como ocorre com a subjetividade, cuja representação póstuma é Fim de partida, também o herói é abandonado; da liberdade só se conhece aquele reflexo impotente e ridículo de decisões que não são nada. Também nisso as peças de Beckett são herdeiras dos romances de Kafka [...] Aquilo que impede a dramatização dos romances de Kafka se torna sua responsabilidade. (Adorno, op. cit., pp. 302-303)

A paródia caracteriza os diferentes matizes do conflito entre Hamm e Clov: a impossibilidade de terminar, a ausência de um desenlace capaz de conferir 
unidade e sentido retrospectivo à ação transcorrida. De modo geral, ela resulta do processo de racionalização imanente à arte moderna. No caso específico de Beckett, este processo se desdobra na apropriação do "material artístico mais avançado", localizado por Adorno, de modo bastante polêmico, nos romances de Kafka, um autor que Beckett nunca reconheceu como próximo. ${ }^{5}$ Cabe aqui uma observação à parte. É evidente que Adorno sustenta esta questão da "paródia do drama" com o conceito de material artístico, desenvolvido por ele em seus trabalhos sobre Schönberg (também citado nestas mesmas páginas do ensaio sobre Beckett), em especial na "Filosofia da Nova Música". A pertinência da transposição deste conceito para a análise da literatura e do teatro é uma questão que permanece em aberto dado o tratamento fornecido por Adorno ao problema. Mesmo na "Teoria Estética", quando aborda "o conceito de material", a referência continua sendo Schönberg, como se deduz da afirmação de que o conceito de material só assumiu forma consciente na década de 1920. Embora a referência a este conceito seja pertinente à análise do drama, na medida em que material significa "tudo com que o artista trabalha", uma abordagem mais rigorosa de seu progresso, tal como feito na música, está ausente do trabalho de Adorno sobre Beckett. Ele limita-se à disponibilização das convenções dramáticas e à referência ao romance kafkiano como o material mais avançado. Referências a T. S. Eliot e James Joyce como fontes deste material são mencionadas de passagem na abertura do ensaio, mas não recebem nenhum desenvolvimento. A história do drama, por sua vez, aparece numa breve menção à crise do drama naturalista de Ibsen. Ainda que a tese da paródia do drama seja muito elucidativa, o encaminhamento dado à questão do progresso do material artístico em Beckett é bastante lacunar quando comparado ao que ele desenvolveu no campo da música.

Ao aproximar Beckett e Kafka por meio do conceito de material, Adorno retoma tanto seus debates da década de 1930 com Benjamin quanto seu ensaio "Anotações sobre Kafka", escrito ao longo de toda a década de 1940. Em ambos os casos, Adorno defendeu, contra Benjamin, a impossibilidade de se afirmar o caráter cênico das parábolas de Kafka, uma tese que traria, na opinião de Adorno, a malfadada influência de Brecht sobre seu amigo. ${ }^{6}$ Sem entrar nos meandros destas interpretações de Kafka, cabe apenas ressaltar os motivos da resistência de Adorno ao pretenso caráter cênico da obra de Kafka, pois são eles que a aproximam de "Fim de partida". Tais motivos ordenam-se em torno

5 Cf. entrevistas publicadas como apêndice ao livro de Andrade (2001).

6 Cf. carta de Adorno a Benjamin de 17 de dezembro de 1934. Adorno e Benjamin (1995, pp. 94-96). Para um comentário a essa questão, cf. Gatti (2009). 
de uma tese a respeito da história do drama: ele é expressão de condições objetivas para o exercício da liberdade pelo herói: "o drama é possível apenas onde a liberdade é visível, mesmo que ela seja o resultado de uma luta; todo outro tipo de ação é fútil. Os personagens de Kafka são atingidos por um mata-moscas, antes de começarem a se movimentar" (Adorno, 1998a, p. 280). O drama não sobrevive sem a liberdade do herói. Daí resulta a opção de Adorno por caracterizar a obra de Kafka como épica. Os problemas aqui não são menores. Se a obra de Kafka é épica, ela não apresenta, porém, o desenvolvimento não problemático da forma do romance, pois o romance kafkiano é, na visão de Adorno, um herdeiro do expressionismo. Ele não fala do mundo, mas da "subjetividade completamente alienada". Daí seu caráter paradoxal: "Épica expressionista é um paradoxo. Ela narra aquilo que não se deixa narrar, o sujeito inteiramente voltado sobre si mesmo e ao mesmo tempo privado de liberdade, um sujeito que na verdade não existe enquanto tal", mas que é transformado em coisa e levado "a uma objetividade que se exprime através da própria alienação" (Adorno, op. cit., p. 262). É com esta concentração expressionista do mundo ao "eu" que Adorno indica uma explicação do hermetismo dos romances de Kafka. "O princípio hermético é o princípio da subjetividade completamente alienada" (Adorno, op. cit., p. 258). Seria justamente este "princípio hermético" o "material mais avançado" lembrado por Adorno no ensaio sobre Beckett. Apropriado por "Fim de Partida", tal "princípio" resultaria no paradoxo que eleva a peça aos olhos de Adorno: Beckett teria empregado na construção de seu drama um material contrário à configuração da ação dramática, ou seja, a subjetividade alienada que priva o herói do exercício da liberdade.

É, finalmente, esta discussão a respeito da historicidade do material artístico que permite a Adorno vincular o drama de "Fim de partida" - a impossibilidade de terminar - a um diagnóstico de época mais abrangente, a saber, ao tema adorniano do enfraquecimento do sujeito no capitalismo tardio. O fim do drama, sua conversão em paródia de si mesmo, pode ser lido então como cifra de um processo histórico $e$ artístico. Clov não abandona o refúgio, de modo a conferir sentido retrospectivo ao conflito com Hamm, por não dispor das condições de exercício da liberdade disponíveis ao herói do drama burguês. A resolução da ação não é uma constelação possível diante da situação histórica atual do drama. Também é por meio desta posição que Adorno articula sua contraposição às duas linhas de interpretação que marcaram a recepção inicial da peça: a representação da guerra nuclear e o absurdo existencialista. 
Contra as leituras de "Fim de partida" como drama da era nuclear, Adorno lembra como a natureza é referida por Clov após espiar pelas janelas do refúgio: "não há mais natureza". Em termos adornianos: a história não surge na figura da ação dos homens, muito menos como representação de eventos históricos, mas cifrada na paisagem, como termo de um processo de dominação da natureza que extirpou o próprio homem.

O fato de que todos os homens estão mortos é sorrateiramente contrabandeado. [...] A fase da completa reificação do mundo, que não deixou nada além do que foi feito pelo homem, é indistinguível da catástrofe permanente e de mais um processo catastrófico causado pelos homens, em que a natureza foi extinta e após o qual nada mais cresce. (Adorno, GS 11, pp. 285-286)

Embora bastante eloquente, o argumento é insuficiente para evitar que a peça seja reduzida a um drama da guerra nuclear, uma vez que esta poderia muito bem ser a última estação do processo de dominação da natureza. A catástrofe final seria incomensurável à relação entre consciência histórica e experiência individual e, por isto, impronunciável pelos personagens, mas acessível ao crítico atento ao progresso da dominação da natureza. Do mesmo modo como sempre desconfiou da possibilidade de um drama sobre o fascismo, Adorno parece precaver-se apenas contra a representação da magnitude do conflito, reforçando a impossibilidade de transpor seu caráter anônimo à ação de personagens dramáticos.

Todo pretenso drama da era atômica seria o escárnio de si mesmo, simplesmente porque seu enredo já falsificaria de modo reconfortante o horror histórico do anonimato ao transpô-lo em personagens e ações humanas, fitando talvez pasmo os figurões que decidem se o botão deve ou não ser apertado. A violência do indizível seria imitada pela vergonha de mencioná-lo. Beckett o mantém nebuloso. (Adorno, GS 11, p. 286)

O que permite a Adorno afastar "Fim de partida" de um drama temático, interpretável à luz das circunstâncias históricas imediatas é esta menção à "nebulosidade". À luz do diagnóstico do enfraquecimento do sujeito, esta indeterminação é uma consequência da dificuldade de apreensão da realidade histórica pela conformação artística. Uma vez que a produção de uma obra de arte também é uma relação entre sujeito e objeto, o enfraquecimento do sujeito como instância idêntica a si mesma, autônoma e plena de significado afeta o tratamento dos materiais que se apresentam a ele. Mais que a natureza dos conflitos históricos no capitalismo tardio, o que determina o "tabu sobre a história", que pesa sobre "Fim de partida", é esta incomensurabilidade entre o 
curso da história e a capacidade individual de apreendê-la e transformá-la em consciência e experiência histórica. ${ }^{7}$

O tema da "nebulosidade" tem estreita conexão com a questão do realismo em Beckett. Enquanto a recepção inicial desta peça se cindia entre as referências históricas e biográficas palpáveis e as categorias universais de cunho metafísico, diversos estudos - Marjorie Perloff, Ian Kott, Fábio de Souza Andrade - têm buscado reavaliar a referencialidade da peça a estratos de significação exteriores a ela. ${ }^{8}$ Ainda que a gênese dos textos revele uma estratégia de apagamento das referências externas imediatas, é inegável que os materiais cênicos e a linguagem empregados por Beckett estão embebidos de mediações históricas. Deste modo, a discussão do realismo é encaminhado por Adorno por meio de uma tendência à indistinção entre interior e exterior, entre materialidade cênica e representação. O realismo seria enviesado, de segunda ordem. A história não aparece como objeto de representação, mas por meio de seus vestígios, como o "cinza" referido por Clov do alto de sua escada quando mira o exterior com a luneta.

O descompasso entre o curso da história e a capacidade individual de transformá-lo em experiência subjetiva teria minado as chances de sucesso de um realismo de primeira ordem. A ironia do argumento é que esta nebulosidade não é uma arma apenas contra a tese do drama da era nuclear, mas também contra a interpretação do "não há mais natureza" de Clov como termo final do processo de dominação da natureza. O mérito de sua interpretação parece assim estar muito menos neste vínculo entre dominação da natureza e declínio do sujeito do que na explicação da impossibilidade de um realismo artístico como uma "aporia da arte contemporânea". Em outras palavras, a incomensurabilidade entre material e subjetividade vedaria a reconciliação com os objetos necessária ao realismo.

A realidade não reconciliada não tolera na arte nenhuma reconciliação com o objeto; o realismo, que não alcança de modo algum o caráter de experiência subjetiva, silencia a seu respeito, é só uma mímica da reconciliação. A dignidade da arte não se mede hoje pelo modo como ela escapa desta antinomia com sorte ou perícia, mas pela maneira como ela a suporta. Nisto, Fim de partida é exemplar. A peça acata tanto a impossibilidade de ainda se apresentar e trabalhar materiais na obra de arte como era costume no século XIX quanto a evidência de que os modos subjetivos de reação, que substituíram a reprodução na mediação da lei formal, não são algo primeiro e

7 "A irracionalidade da sociedade burguesa em sua fase tardia é renitentemente contrária à possibilidade de ser compreendida; bons eram os tempos em que se poderia escrever uma crítica da economia política dessa sociedade tomando-a pela sua própria ratio" (Adorno, GS 11, p. 284).

8 Kott (1966, pp. 156-159); Perloff (2005, pp. 76-103); Andrade (2010, pp. 24-35). 
absoluto, mas algo último, posto objetivamente. Todo o teor da subjetividade, a qual é necessariamente hipostasiante, é rastro e sombra do mundo, do qual ela recua a fim de não servir à aparência e à adaptação demandadas por ele. (Adorno, GS 11, pp. 291-292)

A exemplaridade de "Fim de partida" perante esta aporia consistiria na elaboração de uma zona de indiferença entre interior e exterior, entre os materiais sem os quais a subjetividade não conseguiria expressar-se e uma espiritualidade que os apagaria. $\mathrm{O}$ material não possui sentido próprio e também não se autonomiza em símbolos da interioridade do indivíduo - como na passagem do drama naturalista para o simbolismo do último Ibsen -, pois este não é mais um complexo autocentrado de sentido. Com isto, as fronteiras entre interioridade e exterioridade ficam borradas: as situações da interioridade se confundem com as do mundo físico. Nesta zona de indiferença, as situações cotidianas que compõem a peça se autonomizam face aos contextos racionais, históricos e psicológicos que as caracterizariam num drama realista. Elas se transformam no "negativo da realidade dotada de sentido", um negativo obtido não da apreensão da realidade, mas do próprio destino da forma dramática.

A tese da paródia do drama indica assim a dificuldade de ainda se sustentar uma concepção de obra de arte como unidade imanente de sentido. As conexões imanentes - sentido de palavras e frases, a conexão significativa entre partes e todo - se referiam a um teor metafísico que se apresenta objetivamente no conjunto do artefato, garantindo a unidade da "estrutura estética do significado" (Cf. Adorno, GS 11, p. 282). A crise desta concepção de obra de arte já havia sido detectada por Adorno, novamente, em Kafka, especialmente na tendência das parábolas kafkianas à alegoria, em virtude da ausência de um sentido imanente à figuração a ser buscado na interpretação: "os momentos individuais de uma obra de arte remetem, em virtude da força que os conecta, para além deles mesmos: a totalidade dos momentos converge em um sentido. Nada, porém, seria mais inadequado no que diz respeito a Kafka" (Adorno, 1998a, p. 240). ${ }^{9}$ A mesma tese reaparece na análise de "Fim

9 E Adorno continua: "Em nenhuma obra de Kafka a aura da idéia infinita desaparece no crepúsculo, em nenhuma obra se esclarece o horizonte. Cada frase é literal, e cada frase significa. Esses dois aspectos não se misturam, como exigiria o símbolo, mas se distanciam um do outro, e o ofuscante raio da fascinação surge do abismo que se abre entre ambos. Apesar do protesto de seu amigo, a prosa de Kafka se alinha com os proscritos também por buscar antes a alegoria que o símbolo. Benjamin a definiu com razão como parábola. Ela não se exprime pela expressão, mas pelo repúdio à expressão, pelo rompimento. É uma arte de parábolas para as quais a chave foi roubada; e mesmo quem buscasse fazer justamente dessa perda a chave seria induzido ao erro, na medida em que confundiria a tese abstrata da obra de Kafka, a obscuridade da existência, com seu o teor. Cada frase diz: "interprete-me"; e nenhuma frase tolera a interpretação" (Adorno, 1998a, p. 240). 
de Partida", em que ideia e configuração também não se unificam como na obra de arte clássica ou simbólica. "A ideia da conformação estética como unidade de ideia e aparência é tão mais ilusória quanto menos os acontecimentos forem supostos em si mesmos como plenos de sentido" (Adorno, GS I-1, p. 282). ${ }^{10}$

Com isto, Adorno constrói um sólido argumento contra a recepção existencialista de Beckett, difundida nos anos 1960 com o rótulo de "teatro do absurdo". Na contramão do que vem sendo exposto até aqui, tal recepção não passaria da restauração de um sentido metafísico decaído, agora sob a forma de uma ausência positivada, de um sem-sentido elevado à posição de chave explicativa. Ao chamar a atenção para o atestado de óbito da metafísica tradicional, da qual ainda viveria o existencialismo, Adorno procura realçar o impacto do curso da história sobre toda ordenação preestabelecida, à qual a arte ainda poderia recorrer como fonte de sentido positivo. O papel desempenhado por Beckett na última seção da "Dialética negativa", as "Meditações sobre a metafísica", não é de modo algum gratuito. A exemplaridade de "Fim de partida" não consiste, porém, de modo algum, numa mera eliminação do sentido como referência da obra de arte, mas, como Adorno afirma na "Teoria estética", em colocá-lo em questão, desdobrando sua história. Em outras palavras, Beckett teria imposto às categorias dramáticas a experiência da dissolução de sentido.

Diante da dificuldade crescente para a subjetividade objetivar-se na linguagem historicamente constituída dos materiais, o sentido imanente da obra se torna um tema do fazer artístico. Mas a emancipação das obras em relação a uma noção metafísica de sentido só é esteticamente significativa quando coloca em questão a ideia de sentido autoevidente. Em outras palavras, elas devem enunciar a ausência de sentido com a mesma determinação com que outrora o organizavam por meio de sua lógica interna. É possível então sustentar que "Fim de partida" lida de modo consequente com esse problema ao tematizar a impossibilidade de terminar. A ação dramática não chega a termo pois lhe faltaria a referência da totalidade, da qual depende a junção de partes e todo em um nexo de sentido. "O pouco, que é ao mesmo tempo tudo, seria que talvez algo se modificasse bem aí. Este movimento, ou seu

10 Naturalmente é possível questionar a especificidade artística desta caracterização da noção de sentido. Adorno estaria contrastando o que ele considera alguns dos elementos mais avançados da arte do pós-guerra com uma concepção simbólica de obra de arte, a qual ele parece tomar de empréstimo da crítica feita por Benjamin, em "Origem do Drama Barroco Alemão", à introdução do conceito teológico de símbolo na estética do tempo de Goethe. "O abuso [do uso do simbólico] ocorre sempre que numa obra de arte a 'manifestação' de uma 'ideia' é caracterizada como um 'símbolo'. A unidade do elemento sensível e do supra-sensível, em que reside o paradoxo do símbolo teológico, é deformada numa relação entre manifestação e essência" (Benjamin, 1999, pp. 336-337). 
adiamento, é a ação. Ele certamente não é mais explícito que o 'algo segue seu curso', repetido como um tema, tão abstrato como a forma pura do tempo" (Adorno, GS 11, pp. 313-314). Como o tempo foi privado da promessa de resolução que marcou a história da ação dramática como um desenvolvimento em direção ao desenlace, a ação perde o telos que a impelia à resolução. O fim não aponta para a libertação de Clov, mas, dada a simetria entre início e fim da apresentação, para a tendência à repetição do círculo temporal esvaziado. $\mathrm{O}$ tableau suspende o conflito numa imagem. "O pêndulo da dialética suspendese", afirma Adorno (GS 11, p. 314), citando o conceito de "dialética em suspensão" de Benjamin.

Cabe aqui uma consideração a respeito da evocação desse termo benjaminiano. Os longos debates da década de 1930 ensinam que Adorno nunca cita Benjamin apenas para retomá-lo. Aqui, a diferença é marcante: a imobilização do curso abstrato do tempo não pode mais ser simplesmente interpretada como uma figura da esperança. A distância entre os dois autores torna-se ainda mais interessante caso lembre-se de que o conceito foi cunhado por Benjamin em seus estudos sobre o teatro épico de Brecht. O conceito de "dialética em suspensão" procurava dar conta dos elementos libertadores descobertos por Benjamin nos mecanismos de interrupção da ação. Esta permitia decompor a cena em seus elementos constituintes, de modo que ela fosse explicitada como um arranjo artificial e, portanto, historicamente transformável. Suas objeções a Benjamin na época, bem como sua crítica posterior ao teatro brechtiano, salientam o enfraquecimento desta possibilidade transformadora inscrita na ideia de interrupção. O curso recente da história não teria apenas privado a ação de seu telos, mas também a interrupção de sua dimensão emancipadora. Esta teria migrado para um exercício de negação fundado na observação da legalidade interna do objeto. No caso de "Fim de partida", seu potencial crítico estaria no enfrentamento deste processo de esfacelamento dos pressupostos da forma dramática. A arte manteria seu potencial crítico neste "estudo, como num tubo de ensaio, do drama da época atual, a qual não tolera mais o que constitui o drama" (Adorno, GS 11, p. 303). Não é à toa que Adorno conclua o ensaio aproximando "Fim de partida" da descrição feita por Proust da morte de Bergotte. Consciente da proximidade da própria morte, Proust iniciou um registro minucioso do avanço de sua doença de modo a incorporá-la na descrição da morte do escritor preferido de seu narrador. Beckett, que escreveu uma monografia sobre Proust nos anos de juventude, teria apresentado um diálogo semelhante com o fim. A irresolução de "Fim de partida" afirma que a morte não é uma demarcação nítida entre a vida e sua extinção. A vida não tem mais em seu término o telos que a coroa 
como um percurso dotado de sentido. Como na história do caçador Grachus de Kafka, a morte é apenas a convivência cotidiana com um processo em desintegração.

Os textos de Benjamin sobre o teatro épico, por sua vez, para não mencionar os textos do próprio Brecht, destoam da reflexão teatral de Adorno por recusarem tal primazia do drama. É certo que Brecht introduziu modificações profundas na dramaturgia, de modo a extrair as cenas do curso da ação e conferir a elas um caráter episódico, independente de um todo previamente traçado. $\mathrm{O}$ cerne da reflexão sobre o teatro épico está, contudo, na colaboração entre esta dramaturgia e um conjunto sofisticado de técnicas de encenação. "A encenação, diz Benjamin, não significa mais a interpretação virtuosística do texto, mas seu controle rigoroso. $\mathrm{O}$ texto não é mais o fundamento da encenação, mas a tabela onde seu rendimento é registrado em novas formulações" (Benjamin, GS II-2, p. 520). O processo de encenação não conquista só independência perante o texto, mas também prioridade. Nada mais distante da estética de Adorno. Não se trata aqui de comparar ambos, mas de localizar o papel conferido por Adorno à encenação. Como nota de rodapé a esta questão, vale apenas dizer que o trabalho de Beckett como diretor de teatro se aproxima muito desta posição defendida por Benjamin. Seria então possível supor que sua encenação de "Fim de partida" para o Schiller Theater de Berlim em 1967, cuja análise exige um outro ensaio, daria margem a interpretações distintas daquela empreendida por Adorno (cf. Gontarski, 1992).

Foi visto acima que o privilégio concedido por Adorno ao drama decorre do processo de objetivação da obra de arte, o qual seria responsável tanto por distingui-la da "empiria" quanto por despertar nela a revolta contra esta distinção. Autoconsciente de seu caráter de aparência, a obra denuncia a mentira que cerca sua instauração como um domínio distinto da realidade. O interessante da "Teoria estética" de Adorno reside em não concluir desta aporia da aparência a necessidade de eliminá-la do âmbito da arte. A aparência é indissociável do caráter de objeto da obra de arte. Daí decorre que Adorno nem abandone o conceito de obra de arte, nem veja com bons olhos práticas artísticas que buscariam devolver a arte ao fluxo da vida real, libertando-a de seu caráter de coisa. Ainda que Adorno tenha se dedicado a elaborar uma teoria da reprodução musical, onde propõe uma sofisticada relação dialética entre notação musical e performance, sua posição é restritiva à compreensão de fenômenos como o happening, a performance, a instalação e mesmo a aproximação, nas últimas décadas, entre o teatro e estas práticas artísticas. A "Teoria estética" teria dificuldades em transitar por terrenos em que a arte 
rejeita o caráter de objeto ou exige a presença do receptor para se configurar como experiência estética. Diante da teoria do teatro contemporâneo (a teoria do teatro pós-dramático), contudo, a apego de Adorno ao conceito de aparência ainda tem algo a dizer. Ele permite pensar as práticas teatrais atuais sem abandonar o conflito entre representação e situação teatral. Em outras palavras, sua severidade é necessária contra a apologia da situação teatral que reduz o teatro ao que Hans-Thies Lehmann definiu como a "percepção afetiva e sensível de um momento de vida inscrito na participação real-corporal do espectador" (Cf. Lehmann, 2005, p. 189). Os elementos corporais e materiais da experiência teatral não exigem necessariamente a dissolução completa da representação ou da mimèsis, mas, justamente ao provocar outras formas de teatralidade, os inserem em uma nova relação com as práticas teatrais.

É neste momento que "Fim de partida" se mostra atual, pois é justamente este o seu problema: a relação entre o drama e o teatro. Retomar o modo como Adorno apresenta a questão, esquivando-se da consideração da peça como teatro, pode encaminhar a discussão. Se sua reflexão a respeito da paródia do drama ilumina a tendência anti-ilusionista inscrita em "Fim de partida", ela pouco influi no ilusionismo como critério de composição do espetáculo. Em outras palavras, sua abordagem do teatro é, de modo geral, limitada por compreender a encenação simplesmente como o componente ilusionista do teatro. Se a obra é uma construção racional que, segundo seu próprio conceito, busca refletir sobre seu caráter de aparência, ela será tanto mais verdadeira quanto mais for capaz de incorporar, como uma necessidade imanente, esse seu "outro", indicado por Adorno como o não conceitual, o ilusionista, ou ainda, o mimético. O elemento heterogêneo é imanente a elas (Adorno, GS 7, p. 138). É justamente este o "papel” conferido por Adorno à encenação, ao componente "vivo" do teatro.

A camada pré-artística da arte é simultaneamente a recordação de seu traço anticultural, de sua desconfiança da antítese em relação ao mundo empírico, a qual deixa intocado o mundo empírico. Obras de arte significativas almejam, contudo, a incorporar aquela camada hostil à arte. Onde ela falta, por suspeita de infantilidade [...], no drama sem ilusão que apagou o último resquício da magia do cenário, a arte capitulou. Mesmo sobre Fim de partida de Beckett a cortina se ergue prometetora; peças teatrais e práticas de encenação que a abandonam saltam sobre sua sombra com um truque desamparado. O momento ali em que a cortina se levanta é, porém, a expectativa da aparição. Mesmo querendo exorcizar o colorido do circo, as peças de Beckett, cinzas como o instante após o pôr-do-sol e o fim do mundo, são fiéis a ele ao serem encenadas sobre o palco; e sabe-se o quanto seus anti-heróis foram inspirados pelos clowns e pelas comédias-pastelão. Sua austeridade também não implica de modo algum abrir mão de todo figurino e cenário: o ajudante Clov, que em vão gostaria de partir, veste-se como um viajante inglês, a colina de areia em Dias felizes iguala-se às formações do oeste americano. (Adorno, GS 7, pp. 126-127). 
Consequências importantes para a interpretação de "Fim de partida" decorrem desta concepção de obra de arte como dialética de mimèsis - a ilusão - e construção racional: se a racionalidade artística está na objetivação da arte em obra, todos os elementos mais próprios à tradição da encenação teatral se tornam o "outro" da forma racional. A obra de arte autônoma incorpora a dialética entre ilusão e realidade como um momento de sua formalização. No caso do teatro, ela acolhe os mecanismos ilusionistas de encenação em sua estrutura racionalizada. Adorno parece não levar em conta que a encenação também sofreu algo comparável a este "processo de racionalização" encontrável no drama. Elementos como o vestuário, a cortina e o palco italiano, para ficar naqueles mencionados por ele, não são explicáveis somente como o componente mimético acolhido pela obra racionalizada, mas também se transformam ao longo da história do teatro e estabelecem relações diferenciadas com o efeito ilusionista. Contra Adorno, vale aqui o lembrete de Brecht: na história do teatro, a exigência de naturalidade (o ilusionismo) variou segundo o grau de desenvolvimento técnico. Ela não se impôs a Shakespeare como se colocaria a Goethe (Brecht, 1967, p. 300). Do mesmo modo, foi a transformação das técnicas de encenação - incorporando elementos das técnicas do rádio e do cinema - que tornou possível algo como a formulação, pelo mesmo Brecht, de técnicas de encenação com função anti-ilusionista.

Algo semelhante ocorre com sua interpretação do vínculo entre Clov e a tradição de humor físico do clown e das comédias-pastelão. Tal relação é possível somente a partir de uma forma de racionalidade - a obra de arte autônoma - capaz de acolher seu outro sem causar-lhe violência. É assim que a obra de arte racionalizada rememora a pré-história humana como o animal primitivo recalcado pela civilização. O viés freudiano do argumento de Adorno transforma o humor físico na exposição da regressão da subjetividade a um estado genético primitivo, ou seja, a seu limite físico. Retomando implicitamente suas objeções à valorização por Benjamin da gestualidade do teatro épico, Adorno não vê o clown por meio da interação entre o corpo humano e a técnica teatral, mas pela regressão do indivíduo à existência biológica, algo que ele já havia exposto em seu ensaio sobre Kafka: o gesto é um elemento pré-linguístico, signo da revolta de uma experiência recalcada pela redução da linguagem ao conceito. ${ }^{11}$ A obra de arte autônoma, por sua vez, assim como o ensaísmo filosófico, seriam formas de racionalidade capazes de acolher o elemento mimético do pensamento. Este, pela dialética entre 
conceito e exposição; aquela, pela dialética de aparência e construção racional. Em sua defesa rigorosa da autonomia do drama, o clown e, no limite, a própria presença física do ator no palco permanecem intocados pela racionalização dos materiais artísticos. Adorno não leva em conta nem a construção do movimento corporal pela técnica teatral, nem as transformações da tradição do clown pelo cinema silencioso. De modo geral, todos estes elementos servem à composição de uma invariável ilusionista que a arte mais avançada não pode abolir sob o risco de perda da dialética entre mimèsis e racionalidade.

\section{Referências}

ACKERLEY, C. J., GONTARSKI, S. E. “The Faber companion to Samuel Beckett”. London: Faber \& Faber, 2006.

ADORNO, T. W. “Gesammelte Schriften”. Frankfurt am Main, Suhrkamp, 1991. . "Eine Dokumentation zu Adornos Beckett-Lektüre". In: Frankfurter Adorno Blätter III. Herausgegeben vom Theodor W. Adorno Archiv. München, Text + Kritik, 1992.

. "Ästhetische Theorie, Gesammelte Schriften 7". Frankfurt am Main: Suhrkamp, 1997.

. "Anotações sobre Kafka". In: Prismas: crítica cultural e sociedade. São Paulo: Ática, 1998a.

."Em defesa de Bach contra seus admiradores". In: Prismas: crítica cultural e sociedade. São Paulo: Ática, 1998b.

. "Prismas: crítica cultural e sociedade". São Paulo: Ática, 1998c.

. "Notas de literatura I". São Paulo: Ed. 34, 2003.

. "Zu einer Theorie der musikalischen Reproduktion". Frankfurt am Main:

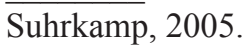

. "Dialética negativa". Rio de Janeiro: Jorge Zahar, 2009.

ADORNO, T. W., BENJAMIN, W. "Briefwechsel 1928-1940". Frankfurt am Main: Suhrkamp, 1992.

ADORNO, T. W., HORKHEIMER. "Briefwechsel II: 1938-1944". Frankfurt am Main: Suhrkamp, 2004.

ALMEIDA, J. "Crítica dialética em Theodor Adorno: música e verdade nos anos vinte". Cotia: Ateliê Editorial, 2007.

ANDONIAN, C. C. "The critical response to Samuel Beckett". Westport, London: Greenwood Press, 1998.

ANDRADE, F. S. “Samuel Beckett: o silêncio possível”. Cotia: Ateliê Editorial, 2001. . "Caindo na real: notas sobre o realismo inusitado em Beckett e Eurípides".

Literatura e Sociedade, v. 10, n. 2, pp. 24-35, 2010.

BECKETT, S. "The Grove Centenary Edition". Vol. 1-4. New York: Grove Press, 2006. 
. "Endspiel, Fin de partie, Endgame". Frankfurt am Main: Suhrkamp, 1974. "Fim de partida". São Paulo: Cosac \& Naify, 2002.

BENJAMIN, W. “Gesammelte Schriften”. Frankfurt am Main: Suhrkamp, 1999.

BRECHT, B. "Gesammelte Werke". Frankfurt am Main: Suhrkamp, 1967.

. "Schriften I" (Über eine nichtaristotelische Dramatik/Das epische Theater).

In: Gesammelte Werke. Frankfurt am Main: Suhrkamp, 1967.

ESSLIN, M. "The theatre of the absurd". New York: Vintage Books, 2004.

GATTI, L. "Constelações: crítica e verdade em Benjamin e Adorno". São Paulo: Loyola, 2009.

. "Exercícios do pensamento. Dialética negativa de Theodor W. Adorno", Novos Estudos Cebrap, Nr. 85, 2009.

GONTARSKY, S. E. (ed.). "The Theatrical Notebooks of Samuel Beckett: Endgame”. London: Faber \& Faber, 1992.

GRAVER, L.; FEDERMAN, R. (ed.). "Samuel Beckett: the Critical Heritage". London, Henley and Boston: Routledge \& Kegan Paul, 1979.

KÖNIG, H.-D. (Hrsg.). "Neue Versuche, Becketts Endspiel zu verstehen”. Frankfurt am Main: Suhrkamp, 1996.

KOTT, J. “A note on Beckett's realism”. The Tulane Drama Review, Vol. 10, Nr. 3, pp. 156-159, Spring 1966.

LEHMANN, H. T. "Postdramatisches Theater". Frankfurt am Main: Verlag der Autoren, 2005.

MENKE, C. "Die Souveränität der Kunst. Ästhetische Erfahrung nach Adorno und Derrida”. Frankfurt am Main: Suhrkamp, 1991.

. "Die Gegenwart der Tragödie. Versuch über Urteil und Spiel". Frankfurt am Main: Suhrkamp, 2005.

PERLOFF, M. "In love with hiding: Samuel Beckett's war".. The Iowa Review, Vol. 35, Nr. 1, pp. 76-103, Spring 2005.

REBENTISCH, J. "Ästhetik der Installation”. Frankfurt am Main: Suhrkamp, 2003. SILVA, E. S. N. "Filosofia e arte em Theodor W. Adorno: a categoria de constelação". 2006. Tese (Doutorado) - FAFICH/UFMG, Belo Horizonte, 2006.

SZONDI, P. "Schriften I-II". Frankfurt am Main: Suhrkamp, 1978.

THE BRECHT YEARBOOK 27. "Where extremes meet: Rereading Brecht and Beckett". Madison: University of Wisconsin Press, 2002.

WELLMER, A. "Zur Dialektik von Moderne und Postmoderne. Vernunftkritik nach Adorno". Frankfurt am Main: Suhrkamp, 1985.

. "Endspiele: Die unversöhnliche Moderne”. Frankfurt am Main: Suhrkamp,

1993.

. "Das musikalische Kunstwerke". In: A. Kern, R. Sonderegger. Falsche Gegensätze. Frankfurt am Main: Suhrkamp, 2002.

. "Über Negativität und Autonomie der Kunst. Die Aktualität von Adornos Ästhetik und blinde Flecken seiner Musikphilosophie". In: A. Honneth (Hrsg.). Dialektik der Freiheit. Frankfurter Adorno Konferenz 2003. Frankfurt am Main: Suhrkamp, 2005. 